\title{
The processing of Kgosi Bathoen II private archives collection for increased access to archives
}

\section{Tshepho Mosweu}

University of Botswana

mosweutl@ub.ac.bw / lydhoss@gmail.com

https://orcid.org/0000-0002-2144-7544

Received: 15 March 2021

Revised: 10 May 2021

Accepted: 17 August 2021

\begin{abstract}
National archival institutions are responsible for the acquisition, preservation and making accessible of their nation's documentary heritage. It is on this basis that the Department of Botswana National Archives and Records Services (BNARS) acquires records through the normal transfer of public records from government agencies as well as donations of private archives. The main purpose of this paper is to analyse the processing of private archives of a prominent "Kgosi" in the history of Botswana, Kgosi Bathoen II of the Bangwaketse ethnic group. This is a qualitative study that used literature review to collect data. It also uses the author's personal observation, as she was involved in the acquisition and processing of the Bathoen II archives. The key findings suggest that even though Batswana have not been donating their private archives in high numbers, BNARS have made strides in collecting private archives of prominent individuals in the country. Unlike public records, private archives collections may not come in any logical arrangement, which may be a tormenting exercise for the archivist to process and select what is worth preserving. This paper concludes that despite the difficulties encountered in processing a huge collection of private papers with no order, private papers should follow the normal archives' practice of arrangement and description for eventual access by researchers or users. Additionally, the significance of private archives in filling the gaps found in the national repositories was revealed through Bathoen II collection, as it has information on various aspects of Botswana life, customs, traditions and the people. As such, the collection provides diversity to the nation's documentary heritage and serves as a rich resource for research. This paper also presents lessons learnt in the preservation of private archives in Botswana.
\end{abstract}

Keywords: Access, archival institutions, Bangwaketse, Botswana, kgosi, private archives

\section{Introduction and background}

The Department of Botswana National Archives and Records Services (BNARS) collects private archives as mandated by National Archives and Records Services (NARS) Act of 1978 (amended in 2007). Section 2(b) of this Act defines a private archive as a record created or received by a private individual or body other than an agency of the government or records of enduring value created, received, and maintained by individuals or organisations relating to 
their private and public lives. The Society of American Archivists defines private archives or personal papers (also personal records, private papers) as documents created, acquired, or received by an individual in the course of his or her affairs and preserved in their original order (if such order exists), or nonofficial documents kept by an individual at a place of work (PearceMoses 2015: 291). In line with those definitions, the International Records Management Trust (IRMT) (2009) defines private records as records created, received and maintained by nongovernmental organisations, families or individuals as evidence of their private and personal affairs. For reasons not documented in the literature, Batswana has not been depositing their private archives with BNARS in any considerable numbers. Nonetheless, the family of Kgosi Bathoen II of Bangwaketse in Botswana yielded to a call by BNARS to donate the private archives of Kgosi Bathoen II, which turned out to be the largest collection of archives from an individual donated to the department. The collection was later celebrated to mark the official opening of the Kanye Records Centre, a regional office of BNARS situated in the village of Kanye in the south of Botswana, during International Archives Day in June 2016. Kanye is the administrative capital of the Bangwaketse ethnic group.

Archival institutions do not just acquire and preserve records; they also make them accessible to researchers or users for administrative, reference and research purposes. Therefore, it was imperative for archivists to make the non-arranged records of Kgosi Bathoen II into a logical arrangement to make them accessible. Pearce-Moses (2005) suggests that archivists are not required to preserve 'original chaos' and may arrange such materials in a way that facilitates their use and management without violation of any archival principle. The Bathoen II collection, which mostly consisted of textual records, covers a wide range of subjects. There is a captivating collection of private letters, reports, correspondences, rare books, newsletters, publications, as well as photographs covering different subjects such as religion, chieftainship, sport, music, law, agriculture, education, language, politics and many others (Mosweu 2012). For archives to be accessible, they are subjected to archival processes such as acquisition, accession, appraisal, arrangement, description and preservation. Access to archives forms an integral part in societies as knowledge repositories and the collection of private archives is one way to build such knowledge repositories.

\subsection{About the records creator}

This paper's discussion is centred on the processing of the Kgosi Bathoen II private archives and their eventual accessibility by researchers or users. The word "Kgosi" is a Setswana term for 'chief' or 'king'. To better understand the collection, it is crucial to appreciate the biographical information of the records creator. Bathoen Gaseitsiwe, also known as Bathoen II or affectionately as B2, was born on 13 May 1908. He was the eldest son of Kgosi Seepapitso III and Mogatsakgari Ratshosa (granddaughter of Kgosi Kgama III of Bangwato, historically, another influential ethnic group in Botswana). He was educated in Kanye, Botswana, Tigerkloof and Lovedale in South Africa. In 1928, he was sworn in as the Paramount Chief of Bangwaketse (Barei 2010:72). As highlighted by Otlogetswe (2018), in traditional Tswana society, political power and leadership of an ethnic group is vested in a kgosi who rules from a traditional court. By his stature as the leader of his people, Kgosi Bathoen II was active in the socio-political activities of Bechuanaland, later Botswana. Notably, he is said to have started the first ever Botswana's Agriculture Fair in 1938 with the help of Mr Russell England (the first Agricultural Demonstrator in Botswana). He also contributed towards the building of the Bathoen II Irrigation Dam, Marapalalo and King George Hall as well as the first library in 
Kanye, his home village (Keboetswe 2011). Bathoen II was also involved in recreational activities such as sport (he played tennis), horse riding, and religious activities, and he once served as the President of Bechuanaland Soccer League. He served in different political fora such as the African Advisory Council, where he ultimately became its Chairman, Joint Advisory Council, Legislative Council, and Labour and Social Services, to mention just a few. These bodies provided a forum for discussions between Batswana themselves, and between Batswana and the colonial administration prior to independence. Upon his resignation from the chieftainship in 1969, he became a Member of Parliament under the Botswana National Front ticket, an opposition political party in Botswana. He was also a member of the London Missionary Church, the modern day United Congressional Church of Southern Africa. He died on 3 October 1990 while he was the President of the Customary Court of Appeal, Botswana (Keboetswe 2011, Mosweu 2012).

Bathoen II's active participation in the development of Bechuanaland (Botswana after independence) was recognised, as shown by several awards and honours he was awarded during his lifetime. The British colonial government awarded him the Officer of the Most Excellent Order of the British Empire (OBE) honour in 1946 and Commander of the Most Excellent Order of the British Empire (CBE) in 1957. His people, the Bangwaketse, celebrated his $25^{\text {th }}$ Silver Jubilee in 1953 (Keboetswe 2011). According to Barei (2000:65), before and during the colonial period, chieftainship was the cornerstone of Botswana's political life. After independence in 1966, the institution underwent drastic reforms in terms of role, influence and respect. Despite the introduction of a series of legislative reforms by the post-colonial government, which curtailed and eroded some powers of the dikgosi, chieftainship still played a crucial role in the lives of ordinary people. It therefore goes without saying that Kgosi Bathoen II's private archives collection would be significant in the archives of Botswana.

\subsection{Problem statement}

The NARS Act of 1978 (amended in 2007) gives BNARS the mandate to collect private archives. Although the Mmegi Online (2008) Newspaper reports that BNARS has been proactive in requesting private archives and made progress in acquiring collections from different stakeholders such as missionaries, churches, associations, imminent persons and politicians, there is a lack of empirical research in this area. A review of a BNARS publication A guide to the contents of the Botswana National Archives and Records Services revealed that BNARS houses a large collection of colonial archives and public records collected postindependence, while there are very few private archives collections (BNARS 2006). These low numbers of private archives collections at BNARS can be attributed to the fact that before the amendment of the national archival legislation in 2007, the Act did not specifically mandate BNARS to collect, preserve and give access to private archives. Furthermore, Botswana does not have a long history of archives administration, as it was only in 1965 when colonial records relating to Bechuanaland were transferred from Mafikeng (former capital city of Bechuanaland located in South Africa) to Gaborone, which saw the setting up of the national archives (Keakopa 2018). It is argued by Bhebhe and Mosweu (2018) that archival institutions used to be the domain of state governments whereby the national narrative churned out was that of the elites or those in positions of power. Hence, it is imperative to analyse the acquisition and processing of private archives of Kgosi Bathoen II by BNARS to establish their significance in the national archives repository. 


\subsection{Research purpose and objectives}

The purpose of this paper is to analyse the processing of private archives of Kgosi Bathoen II of the Bangwaketse ethnic group in Botswana. The specific objectives are to:

1) Establish the steps in processing of private archives of Kgosi Bathoen II by BNARS.

2) Discuss the acquisition of private archives of Kgosi Bathoen II by BNARS.

3) Examine the arrangement and description of private archives of Kgosi Bathoen II by BNARS.

\section{Methodology}

This paper used the qualitative approach and reviewed literature to analyse the acquisition and processing of private archives of Kgosi Bathoen II at BNARS. Moreover, the paper infuses personal observations of the author during the processing of the collection. The paper reviewed secondary sources of information such as journal articles, books, newspapers, legislation and internet sources to collect data on the processing of private archives of Bathoen II, and private archives in general. The paper is influenced by archival theory and practice.

\section{Literature review}

This section presents the literature review to address the research objectives.

\subsection{Processing of archives}

Processing involves the arrangement and description of the acquired records to produce finding aids for easy access to archival materials. For an effective undertaking of these activities, an archival institution should design policies that guide the processes. In this case, a processing manual is one tool that should be in place to guide archivists in the processing of archives and for uniformity and consistency. A processing manual includes the definition of archival terms, elaboration of how the different steps of processing should be carried out such as acquisition, arrangement and description, labelling, as well as an explanation of archival principles used in processing. According to Ramos and Ortega (2006), processing is a term usually used in archives to describe the process of ridding a collection of non-archival materials and readying it for arrangement at description. Different scholars in the field of archives argue that processing involves several steps (Ramos \& Ortega 2006; Walne 1984; Desnoyers (1988). According to Walne (1984), processing is a collective term comprising recording acquisitions, arrangement, description, and preservation. For Desnoyers (1988), processing comprises the archival processes of arrangement, preservation, and description, plus the activity of screening, which is unique to personal papers. Although these scholars describe processing through those activities, Greene and Meissner (2005) argue that archival literature has been inconsistent in defining the parameters of processing. This paper takes processing to mean the acquisition, arrangement and description as well as the preservation of archival materials.

\subsection{Acquisition of archives}

An archival institution can only refer to processing when it has an acquisition or acquired materials. Acquisition is the way in which an archival institution gets materials into its custody. These materials come from different sources such as the natural transfer of records from creating agencies, purchasing, donations, gifts loans, gifts and bequests (Fisher 2015; BNARS 
2010a). There must be an acquisition policy in place to guide the institution in getting archival materials into its custody. BNARS has an acquisition policy that is meant to define the scope of acquisition and provide guidelines for acquiring additional materials to its holdings (BNARS 2010a:1). Schwirtlich and Reed (1993:137) argue that "the acquisition policy defines the nature of the archives. It stipulates what the archives will acquire, what limits it will set on acquisition and what types of material are of particular interest". It is important to highlight the fact that as long as the policy can set limits for the acquisitions and the type of materials an institution is interested in, there is a possibility that some information may never reach the researchers or users. Hoverstock and Baird (2006) highlight the fact that archivists have a challenging role in making decisions that affect how users interpret and research collections. These authors are of the view that no archivist can anticipate users' needs now or in the future, as user needs for a particular collection may change over time, as will the significance and meaning of the papers in a collection.

Although the aims of an acquisition policy are appreciated as the policy acts as guidance for what to acquire, it may be used by an archival repository to refuse materials that do not conform to their specifications from donors or archival principles. That on its own could lead to the denial of some archival information to some users. Apart from that, acquisition may also have an impact on access in the sense that, an archival institution or repository, may have to purchase some archival materials. If an institution has inadequate financial resources, as is normally the case for most archival institutions in Africa, some users' information needs would not be met.

\subsection{Arrangement and description of archives}

Archival arrangement may be described as the systematic organisation of archival materials using archival principles of provenance and original order in archival theory and practice. These principles require that archivists manage the records of separate agencies separately and maintain the original order of creation and arrangement. Dunham (2015:3) points out that the principles work together to provide the archivist and the researcher with information about the context in which the records were created and used. It is this context that influences the records' content and coverage such that it can provide valuable information about the attitudes the records reflect. It should be noted that, sometimes, order does not exist, especially in private archives collections. In such cases, archivists are forced to impose a sensible order when arranging the records for easy access to information. It is also noticed by Prom (2007) that, where possible, archivists need to try, by all means, to retain or recreate original order to preserve the evidential value of records. Moreover, Roe (2005) warns that it is important to consider ease of access and understanding before creating an artificial arrangement. Trace (2015) points out that there has been a major debate about whether the hierarchical and standardised levels of control adequately represent the complex network of provenancial and recordkeeping relationships.

The arrangement and description of archives are normally undertaken at the same time. Ramos and Ortega (2006) point out that as one processes a collection, one is already organising and placing materials in a particular arrangement; and this goes hand in hand with description, which will ultimately result in a finding aid. Even though Thibodeau (2015) contends that there are many definitions of archival description, it can be defined as the capturing or recording of standardised information about the records so they can be used by researchers or users. According to Walne (1984:59), archival description "is the preparation of finding aids to 
facilitate control and consultation of holdings". To elaborate on this, Thibodeau (2015:39) posits that when archivists describe, they capture, collate, analyse, and organise information about a whole recordkeeping system. The product of the description process is a finding aid that may be in the form of a guide, inventory, descriptive list, catalogue, location register or index to facilitate access. As finding aids differ, the selected type may have an impact on access to the archives. Desnoyers (1988) advices that archivists should consider the nature of the collection and the needs of researchers when deciding on the form of description that is proper for each individual collection. Thibodeau (2015) argues that the history of archival description has recently been affected by the advent of networked computing and recognition of common interests among archivists, librarians, and scholars.

As per European archival practice adopted in Botswana, by virtue of the country being a former British protectorate, arrangement is normally done at any of the five levels, which are repository level, group/collection level, series level, file level and item/document level. It has been argued by Greene and Meissner (2005) that the many traditional approaches to processing collections that archivists continue to practice result in processing backlogs. This shows that the kind of approach an archival institution chooses for processing its collections has an impact on the extent of records that may be processed and therefore may impact on access to archives. If records are not processed well in time, accumulation of unprocessed records would deny researchers or users access to the information they need. Nevertheless, Trace (2015) is of the view that an understanding of archival arrangement continues to evolve, as archivists refine the activities and principles on which arrangement is based.

\subsection{Preservation of archives}

As part of processing, preservation has been described by Walne (1984) as the basic archival function of storing and protecting archives or the totality of processes involved in the physical protection of archives against damage or deterioration and the repair of deteriorated documents. Pearce-Moses (2015:74-75) states that preservation has three different meanings, that is (a) collecting manuscripts to a designated safer storage, (b) the storage, use and handling, collections maintenance, reformatting, conservation treatment, and disaster planning (c) litigation hold used within a legal context to prevent records from routine destruction based on a retention schedule when there is reasonable anticipation that the records may be potentially relevant to litigation, audit or investigation. This paper is more aligned to preservation as an archival function of keeping and maintaining archival materials such that they remain accessible to the users as long as they are needed. It is important to note that during the processing of textual records, the archivist may undertake basic preservation measures such as removing staples, paper clips, rubber bands, and unfolding pages, and identifying materials that are fragile. All these activities could delay processing and result in inaccessible archives or backlogs in processing archival materials. Apart from that, preservation has an impact on access to archives as users may be denied access to some materials that are fragile. Forde (2007:199) argues that "the desire to promote access is irreproachable: the difficulty comes with the inevitable damage caused to the documents as they are endlessly extracted from storage, taken to a distribution centre or reading room, handed over to the reader and then returned." Therefore, archival institutions need to strike a balance between providing access to archival materials and protecting these records for continued preservation. 


\section{Discussion and recommendations}

This section discusses the findings of the study according to the research objectives.

\subsection{Processing}

This paper established that the processing of Kgosi Bathoen II, which was done by a group of six BNARS archivists at most, was mainly guided by the General International Standard Archival Description (ISAD (G) Second edition). This standard provides general guidance for the preparation of archival descriptions developed by the International Council on archives (ICA) and adopted for this exercise by BNARS, a member of ICA. It was used in conjunction with BNARS policies and guidelines such as the processing guidelines and the acquisition policy. The archival principles of Provenance and Original Order were also observed as per archival theory and as outlined in the BNARS Processing Guidelines (BNARS 2010b). As it is the nature of private archives, some records in the Bathoen II collection were not in any logical arrangement, while others had no titles and archivists had to impose some order. It was observed that although the records creator made some effort to file and keep some records in folders, others were clipped together, and some were just loose sheets of papers. In this instance, archivists had to be diligent in arranging loose papers in such a way that the evidential value of the records could not be lost. The processing of Kgosi Bathoen II's private archives started with their acquisition before they could be arranged and described for preservation and access.

\subsection{Acquisition}

The importance of the acquisition of private archives from the local people cannot be overemphasised, especially in Africa where national archival repositories largely contain colonial records. This paper found that Batswana were not donating their private archives in large numbers for preservation and access at BNARS. Nonetheless, in line with the BNARS acquisition policy, which directs BNARS to acquire private archives, the department contacted the Bangwaketse Royal Family in Kanye to consider the possibility of donating Kgosi Bathoen II's private archives for permanent preservation. The family realised that BNARS would be the best place to safely keep the records and they donated the records. The collection has rich historical and research information pertaining to Kgosi Bathoen II's life and the historical development of his home village, Kanye, Ngwaketse area and Botswana, as a whole. The records were found locked up in Bathoen II's private library already being eaten by termites and moths as the library had been locked for 20 years since the passing of Kgosi Bathoen II in 1990. As per the BNARS processing guidelines, the papers were boxed for transportation to BNARS, which requires that each acquisition should be recorded in the accession register. This acquisition register provides all administrative and legal information regarding newly acquired collections. A preliminary stocktaking was conducted by archivists to identify the order and organisation of materials. At the time BNARS acquired the Bathoen II private archives, there were only 33 collections of private archives from individuals, private organisations and nongovernmental organisations.

\subsection{Arrangement and description}

Arrangement and description of archives should follow their acquisition as dictated by archival theory. A review of the BNARS processing guidelines indicated the need for archivists to 
discuss the collection's arrangement or lack of order with the appropriate supervisor during the arrangement of private archives (BNARS 2010(b):5). With a big collection as that of Kgosi Bathoen II, consultations among archivists were an important task to undertake. As there was no distinct order to the collection, the records were organised according to series categories, which helped to find a preliminary scope and content statement for the collection, and with the identification of items with research value, and those that were unique and not already available at BNARS repositories. The difficulty in arranging personal papers must be acknowledged here as the processing of Kgosi Bathoen II private archives took months to complete. Trace (2015) points out that there has been strong resistance to the application of archival arrangement in the management of private archives. This argument is understandable as private archives may come with no logical order and hence take time to arrange and describe. After the Bathoen II records were arranged in a logical manner, a written finding aid for the collection describing materials at item level within each series was generated using the BNARS processing forms.

Pearce-Moses (2005) posits that the purpose of creating a finding aid is to allow users to browse a surrogate of the collection to facilitate access and to improve security by creating a record of the collection as well as to minimise the handling of the original materials. Over the years, archivists have developed descriptive standards to guide them in describing records so that there is standardisation across archival institutions and, with it, easy access to archives. The common descriptive standards include Encoded Archival Descriptions (EAD), Rules for Archival Descriptions (RAD) and the ISAD (G). Although these descriptive standards serve as a guide to archivists, Thibodeau (2015) is of the view that their availability does not guarantee their successful application, especially where there is a lack of a clear relation of their understanding to one another. Furthermore, Prom (2007:7) argues that "describing materials effectively requires many skills that are not covered in these standards. Not only must archivists master the basics of description, but they must also effectively manage projects, train and supervise subordinates, and use complicated technologies." In other words, where archivists lack the requisite skills, it might not be possible to effectively describe the archives and, consequently, access to archives is impacted negatively.

Ramos and Ortega (2006) contend that supplies and staff time to process collections are the most costly ongoing expenditures to deal with in order to get collections processed on time. For instance, if an archival institution is faced with limited resources like funds and manpower, it may choose to process records at a broad level because it is faster, but might not be sufficient to help users locate the information they need. On the other hand, describing archives at the lowest level may result in backlogs, as Roe (2005) observes that in view of the fact that many archival institutions have huge backlogs of records that are not described, achieving access can be hampered by focusing on describing all records fully. Arrangement and description of the Bathoen II collection took a period of six months, mostly due to the extent of the collection, inadequate manpower, the fragmented nature of private papers and the description of the records at item level.

According to BNARS (2010b:8), the processing guidelines advise archivists to pay attention and remove documents that should not be availed for public consultation. This may reflect badly on any distinguished persons, pose national or security threat, and contain information of a political nature that may harm international relations or relate to information regarding on individual's privacy. This paper established that during the processing of the Bathoen II collection, some records that were deemed to contain information regarding his individual and 
other people's privacy were removed from the collection. Apart from such records, other discards included extra copies of the same document, empty chequebooks and other ephemeral documents. These kinds of documents were returned to the family of Kgosi Bathoen II. The decisions on what to keep or not keep were made in line with the BNARS legislative and policy framework, as well as consultation with other archivists. This practice is consistent with Dunham's (2015:6) argument that when archivists are in doubt, they should consult with their colleagues to determine whether an item should be kept or discarded.

\subsection{Access and accessibility}

The collection of Kgosi Bathoen II was finally processed and made accessible after a period of about six months since its acquisition. BNARS officially opened the collection for public access during the 2016 International Archives Day celebration held in Kanye. As highlighted by the then Minister of Youth Sport and Culture, under which BNARS resorts, Mr Thapelo Olopeng, quoted in the Botswana Daily News (2016), said that the Kgosi Bathoen II private archives collection was a major contribution to the country's heritage. The newspaper reports the Minister to have said the records, which dated as far back as the 1890 s, were a unique collection of private archives accumulated during Kgosi Bathoen's life but were never availed to the public; therefore, would provide information on him and the nation in general. The Minister emphasised the need for the collection to be preserved for future generations, adding that it would enrich the national collection. The Kgosi Bathoen II private archives collection is currently housed and open for public access at Kanye Records Centre, Kanye.

\section{Recommendations}

- In processing private archives, archivists need to observe the provisions of the relevant legislation such as the data protection or privacy laws in their guidelines. This is essential for the protection of the integrity and image of the records creator as it is normal to find sensitive materials in private archives collections.

- Standards, policies and guidelines are crucial tools for archivists in the processing of private archives from the accessioning period until the preparation of finding aids. They are the basis for uniformity and consistency in processing archives. Additionally, standards, policies, and guidelines serve as a training tool and a reference source for archivists.

- A robust outreach programme is imperative for BNARS and other archival institutions in Africa to lobby for more private archives donations, as the collection of Kgosi Bathoen II indicated that some of the valuable records that have a bearing on the country's history and development are in the hands of private individuals and not in the national repository. Private archives have proven to fill the gaps, balance some historical specifics and give diversity to the national documentary heritage.

- As processes of arrangement and description require some technical skills which may go beyond the scope of archival descriptive standards, there is a need for archivists to have some skills and training in areas such as project management, supervision, and information and communication technologies. These skills have a bearing on the time taken to process the records and the efficacy of the processing exercise. 


\section{Conclusion}

This paper revealed that processing archives encompasses several processes such as acquisition, arrangement and description, as well as preservation as informed by archival theory and practice. All these steps have an impact on access to archives. Archivists decide on the kinds of materials they collect and process, and some materials may be discarded in the process. Archivists also use archival policies, principles and standards to guide them in processing. If any of the processing steps is not done efficiently and effectively, there is a danger that some archives may not be accessed by users. Standards, policies and guidelines such as the acquisition policy and processing guidelines proved to be instrumental as guiding tools during processing of the Kgosi Bathoen II private archives. The processing of the Kgosi Bathoen II collection highlighted the mammoth task archivists face with large private archives collections that have little logical arrangement. The collection revealed that private archives enrich the nation's documentary heritage with records that otherwise would be missing from national archives repositories for access and research. Therefore, this paper recommends the collection of more private archives by archival institutions, especially in Botswana and the rest of Africa, as most of the national repositories largely hold colonial and government-generated records.

\section{References}

Barei, G. 2010. The decline in the role of chieftainship in elections. Pula: Botswana Journal of African Studies, 14 (1): 65-75

Bhebhe, B. \& Mosweu, T. 2018. A comparison study of oral history programmes at National Archives of Botswana and Zimbabwe: Postmodernism approach to oral history In Chisita, C.C. \& Rusero, A.M. (Eds.). Exploring the relationship between media, libraries, and archives. IGI Global, Hershey, 160-179. DOI: 10.4018/978-1-52255840-8

Botswana National Archives and Records Services. 2010(a). Acquisition policy. Gaborone: Government printer.

Botswana National Archives and Records Services. 2010(b). Processing guidelines. Gaborone: Government printer.

Botswana National Archives and Records Services. 2006. A guide to the contents of the Botswana National archives and Records Services. Unpublished

Desnoyers, M.F. 1988. Personal papers. In Bradsher, J.G. (Ed.). Managing archives and archival institutions. Chicago: The University of Chicago Press, 78-91.

Dunham, E. 2015. Manuscript and archival records processing manual.

Available at: https://www2.archivists.org/sites/all/files/asu_processing_manual.pdf (accessed 24 January 2021).

Fisher, R. 2015. Acquisition. In: Duranti, L. \& Franks, P. (eds) Encyclopaedia of archival science. New York: Rowman \& Littlefield, 7-8. https://doi.org/10.1080/23257962.2016.1151406

Forde, H. 2007. Preserving archives. London, Facet Publishing.

Government of Botswana. 1978. National Archives and Records Services Act Cap 59:04. Gaborone: Government Printer.

Greene, M.A. \& Meissner, D. 2005. More products, less process. pragmatically revamping traditional processing approaches to deal with late 20th century collections. Available at: 
http://ahc.uwyo.edu/documents/faculty/greene/papers/Greene-Meissner.pdf (accessed 24 January 2021).

Hoverstock, A. \& Baird, R. 2006. Legacy in flight: processing the Marlon D. Green collection. New Library World 107 (7/8): 346-351

International Council on Archives. 2000. ISAD(G): General International Standard Archival Description. 2nd ed. Available at: https://www.ica.org/sites/default/files /CBPS_2000_Guidelines_ISAD\%28G\%29_Second-edition_EN.pdf (accessed 24 January 2021).

IRMT. 2009. Glossary of terms. Available at: http://www.irmt.org/documents/ educ training/term\%20modules/IRMT\%20TERM\%20Glossary\%20of\%20Terms.pdf (accessed 24 January 2021).

Keakopa, S.M. 2018. Management of public sector records and archives in Botswana. In Ngulube, P. (ed). Handbook of research on heritage management and preservation. IGI Global. Hershey, 23-256. DOI: 10.4018/978-1-5225-3137-1

Keboetswe, S.R. 2011. The noblest man that ever lived in the tide of times, Kgosi Bathoen II Mmegi Newspaper. Available at:

http://www.mmegi.bw/index.php?sid=6\&aid=881\&dir=2011/August/Friday12/ (accessed 24 January 2021).

Mmegi Online. 2008. Botswana National Archives and Records Services opens private archives. Available at:

https://www.mmegi.bw/index.php?sid=1\&aid=19\&dir=2008/October/Friday10/ (accessed 21 June 2021)

Monnakgotla, P. 2016. Bathoen's records enrich national archives. Botswana Daily News, 09 June. Available at:

http://www.dailynews.gov.bw/mobile/news-details.php?nid=28953\&flag (accessed 24 January 2021).

Mosweu, T. 2012. Bathoen collection. Tshedimoso Newsletter. Gaborone: Botswana National Archives and Records Services.

Otlogetswe, T. 2018. Power relations in Setswana names: a study of kgotla and kgosi names. Nomina Africana 32(2): 57-71.

Pearce-Moses, R. 2005. A glossary of archival and records terminology. Available at: https://files.archivists.org/pubs/free/SAA-Glossary-2005.pdf (accessed 24 January 2021).

Pearce-Moses, R. 2015. Archival preservation. In: Duranti, L. \& Franks, P. (eds) Encyclopaedia of archival science. New York: Rowman \& Littlefield. New York, 7478. DOI: https://doi.org/10.1080/23257962.2016.1151406

Prom, C.J. 2007. Optimum access? Processing in college and university archives. Available at: http://www.library.illinois.edu/archives/workpap/ChapterEight-Prom.pdf (accessed 24 January 2021).

Ramos, M. \& Ortega, A. C. 2006. Building a successful archival programme: a practical approach. Oxford: Chandos Publishing.

Roe, K.D. 2005. Arranging and describing archives and manuscripts. Society of American Archivists.

Schwirtlich, A. \& Reed, B. 1993. Managing the acquisition process. In Ellis, J. (Ed.). Keeping archives. Port of Melbourne: The Australian Society of Archivists, 273-305. 
Thibodeau, S. 2015. Archival description. In Duranti, L. \& Franks, P. (Eds.). Encyclopaedia of Archival Science. New York, Rowman \& Littlefield, 39-42 DOI: https://doi.org/10.1080/23257962.2016.1151406

Trace, C. 2015. Archival arrangement. In Duranti, L. \& Franks, P. (Eds.). Encyclopaedia of Archival Science. New York, Rowman \& Littlefield, 21-24. DOI: https://doi.org/10.1080/23257962.2016.1151406

Walne, P. 1984. Dictionary of archival terminology. International Council on Archives. Paris, Handbooks Series. (3) 